\title{
INDIVIDUALIZATION OF CUSTOM COMPOUNDED HORMONE THERAPY IN A PATIENT WITH CHEMOTHERAPY INDUCED PREMATURE OVARIAN INSUFFICIENCY AND IMPAIRED LIVER FUNCTION - CASE REPORT
}

\author{
Damir Franić1,2, Matjaž Sever ${ }^{3}$, Andrej Janež ${ }^{4}$, Maja Franić-Ivanišević ${ }^{5}$ and Mojca Jensterle ${ }^{4}$ \\ ${ }^{1}$ Outpatient Clinic Ob\&Gyn, Rogaška Slatina, Slovenia; ${ }^{2}$ School of Medicine, University of Maribor, \\ Maribor, Slovenia; ${ }^{3}$ Department of Hematology, University Medical Centre Ljubljana, Ljubljana, Slovenia; \\ ${ }^{4}$ Department of Endocrinology, Diabetes and Metabolic Diseases, University Medical Centre Ljubljana, \\ Ljubljana, Slovenia; ${ }^{5}$ Department of Gynecology and Obstetrics, Clinical Centre of Serbia, Belgrade, Serbia
}

\begin{abstract}
SUMMARY - Although the use of commercially manufactured hormone therapy (HT) to treat menopausal symptoms has declined during the past 12 years, the use of custom compounded HT seems to have increased. A 39-year-old woman with refractory anemia sustained premature ovarian insufficiency following allogeneic stem cell transplantation. After systemic biologic treatment (azacitidine) and corticosteroid therapy, besides extreme climacteric symptoms (Green Climacteric Scale, 59) and impaired quality of life, she also had elevated liver enzymes. Therefore, she was not a candidate for oral HT. Treatment was started with 17 -beta estradiol patch $0.5 \mathrm{mg}$ (Climara) together with micronized progesterone intravaginally, $2 \times 100 \mathrm{mg}$ (Utrogestan) for 3 months. She was not satisfied, so the custom compound HT started with 17-beta estradiol $0.5 \mathrm{mg}$ gel $2 \mathrm{x} / \mathrm{day}$ and micronized progesterone in liposomal gel $100 \mathrm{mg} /$ daily. She was much better but she complained of low libido, decreased sex drive and emotional instability, so $1 \%$ testosterone gel was added. Now she was completely satisfied, Green Climacteric Scale was 8 and liver enzymes were normal. In conclusion, custom compound HT has the possibility of tailoring and adjusting therapy to the individual need, which has been the everlasting goal in menopause medicine and should be a good option for special clinical cases.
\end{abstract}

Key words: Custom compounded hormone therapy; Individualization; Premature ovarian insufficiency

\section{Introduction}

After the Women's Health Initiative (WHI) study was published in the literature ${ }^{1}$, the use of hormone therapy (HT) has decreased dramatically. In 2010, the prevalence of HT use was only $4.7 \%$ in women over 40 years in the US as compared with $22.4 \%$ in $2000^{2,3}$. Although data in the later WHI publication after 13-

Correspondence to: Damir Franić, MD, Outpatient Clinic Ob\& Gyn, Celjska c. 10, 3250 Rogaška Slatina, Slovenia

E-mail: damir.franic@guest.arnes.si

Received June 29, 2016, accepted February 28, 2017 year follow-up differed from the initial reports and did not show an increase in cardiovascular risk in any age group (with the exception of venous thrombosis), the majority of women still refused to use $\mathrm{HT}^{4}$. However, individualization is the key approach including continuous ongoing assessment and use of new diagnostic tools for efficacy and risk assessment, and therapeutic adjustments as necessary; all these will ensure the best welfare of postmenopausal women ${ }^{5}$.

Custom compounded HT could be a form of personalized medicine whereby the dose, regimen and dosage forms are customized and based on the patient 
symptoms, hormone levels and personal preferences ${ }^{6}$. Since the Food and Drug Administration (FDA) approved HT, it has become the gold standard for therapeutic purposes; however, there are some special cases where FDA HT products do not fulfill individual patient demands. Therefore, in our case report, we present a patient with premature ovarian insufficiency (POI) because of refractory anemia and allogeneic stem cell transplantation, which seriously impaired her quality of life (QoL).

\section{Case Report}

A 39-year-old woman presented with a one-year history of amenorrhea. She had regular menstrual cycles from the age of 14 until after the allogeneic stem cell transplant for refractory anemia with excess blasts in September 2012. The post transplant period was complicated with chronic graft versus host disease $(\mathrm{GvHD})$ of the skin and mucosa. She was treated with a combination of sirolimus and corticosteroids, which both were discontinued in July 2013, i.e. two months before examination at our institution. She continued taking therapy with mycophenolate until December 2014 when GvHD remission occurred and therapy was stopped. She remained in disease remission for 3.5 years after the transplant.

At presentation, she had normal body weight with body mass index of 21. She had normal secondary sexual characteristics, no signs of androgenism and no galactorrhea. She had very severe hot flushing and sweating at night, was unable to sleep and found extreme difficulty in concentrating. Her libido was significantly decreased. Her DEXA T-score L1-L4 was $-1.6 \mathrm{SD}$, left femoral neck -0.2 , total left hip -0.1 SD. She had no prior fragility fracture. Hormonal work-up confirmed elevated follicle-stimulating hormone, normal thyroid-stimulating hormone, normal prolactin, and normal basal and adrenocorticotropic hormone (ACTH) stimulated cortisol levels. Pelvic ultrasound examination showed small uterus with atrophic endometrium and involutive ovaries. Antimüllerian hormone or antral follicle count were not assessed since the patient declined to be referred to the Reproductive Unit, Department of Obstetrics and Gynecology, University Medical Centre Ljubljana, where these biomarkers are routinely assessed because she was not interested in evaluation of her ovarian reserve. We concluded that previous chemotherapy with multiple agents, including high dose busulfan and cyclophosphamide for stem cell transplant conditioning had led to premature ovarian failure causing her severe climacteric problems. Unfortunately, her liver enzymes were elevated in the post transplant period. Derangements of liver enzyme tests are often seen and usually attributed to drug interactions after allogeneic stem cell transplant. In addition, GvHD is a complication occurring in about half of these patients and in its acute form can affect the skin, liver and gut but is commonly seen as an overlapping syndrome affecting several organs. Due to elevated liver enzymes, the patient could not take oral HT, therefore another non-oral option should have been administered to improve her impaired QoL. The climacteric score sheet based on the Greene Climacteric Scale was obtained to objectify her complaints (Table 1). The hormones and liver enzyme laboratory tests before HT are reported in Table 2 .

At first, the following FDA approved HT was administered: 17-beta estradiol in patch $50 \mathrm{mcg}$ (Climara) once weekly + micronized progesterone 200 $\mathrm{mg} /$ day intravaginally (Utrogestan). After three months of treatment, the Green Climacteric Scale of climacteric symptoms was repeated. There was no change in terms of QoL improvement related to the severity of climacteric symptoms. The patient's score was 13 for anxiety, 10 for depression, 3 for sexual, 23 for psychological, 2 for physical, and 4 for vasomotor complaints. She was not satisfied with estrogen patch, she had allergic reactions around the patch, and complained of severe headache especially the first 2 days after the patch had been pasted. Therefore, the route of HT administration was switched to custom compounded HT (CC HT).

The 17-beta estradiol alcoholic gel $0.05 \%(50 \mathrm{mcg} / \mathrm{g})$ $2 \mathrm{x}$ daily on the forearm $+10 \%(100 \mathrm{mg} / \mathrm{g})$ micronized progesterone liposomal gel $2 \mathrm{x}$ daily on the chest was administered. After 3 months, the patient felt much better, with no vasomotor symptoms, but still had emotional instability and no libido. So the local $2 \%$ testosterone thick non-alcoholic gel $1 \mathrm{x}$ daily on the clitoris and labia for 2 months (to induce libido) was added, and then switched to systemic 1\% testosterone micro in liposomal gel. After 3 months of this treatment, the patient achieved complete satisfaction. The Green Climacteric Scale symptoms are shown in Table 3.

Three months after the CC HT was started, the hormone and liver enzyme laboratory tests were re- 
Table 1. Green Climacteric Scale score sheet-before hormone therapy

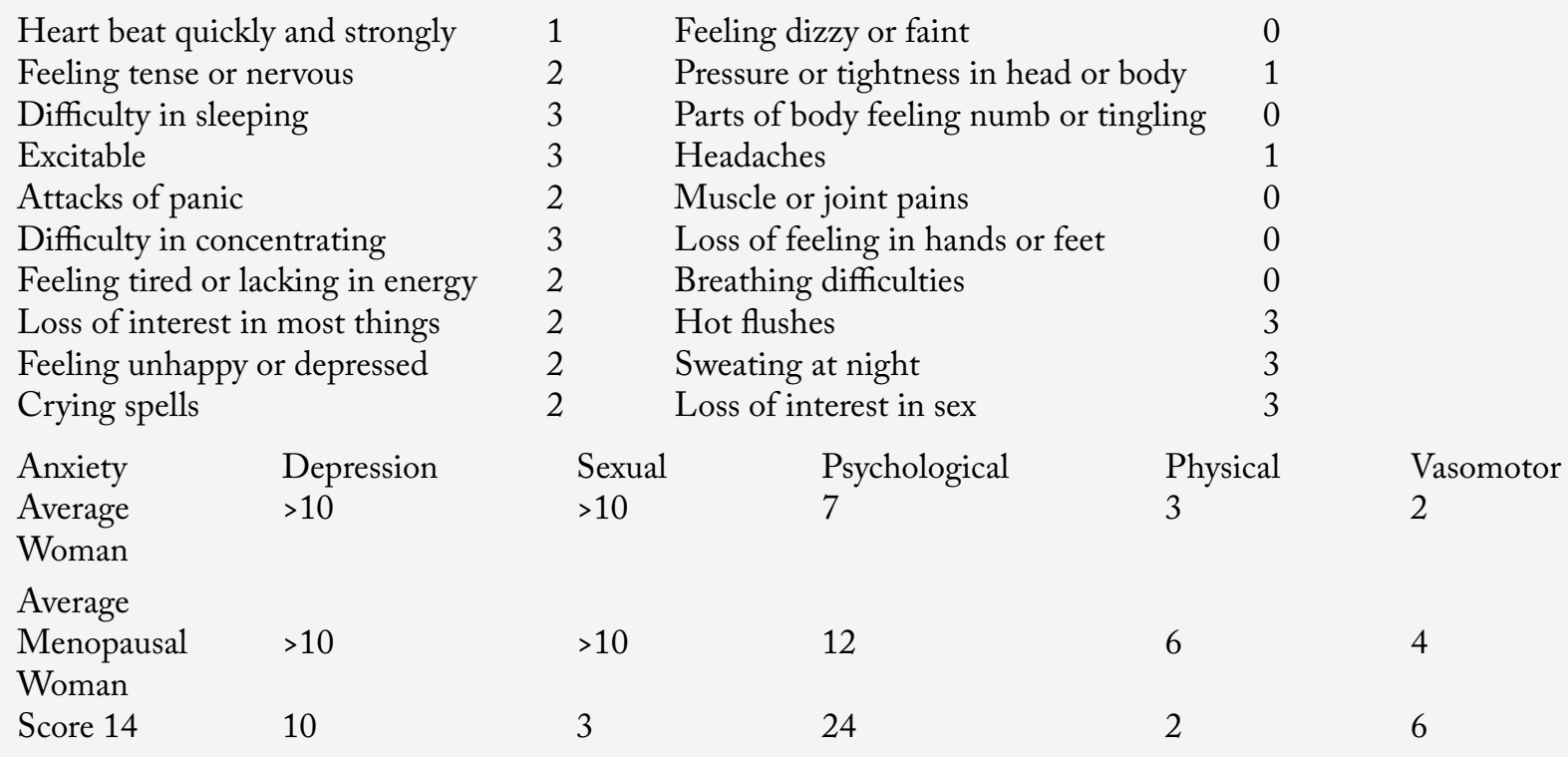

The severity of problem is scored as follows: score $0=$ none; 1 = mild; $2=$ moderate; $3=$ severe

Table 2. Sexual hormones and liver enzymes before hormone therapy

\begin{tabular}{|c|c|}
\hline Sexual hormones before HT & Liver enzymes before HT \\
\hline S-estradiol, 0.081nmo/L (0-0.11) & S-alkaline phosphatase, $3.25 \mu \mathrm{kat} / \mathrm{L}(1.74)^{*}$ \\
\hline S-progesterone, $0.64 \mathrm{nmol} / \mathrm{L}(0.2-3.2)$ & S-AST, $1.36 \mu \mathrm{kat} / \mathrm{L}(0.52)^{*}$ \\
\hline S-testosterone, $0.1 \mathrm{nmol} / \mathrm{L}(0.3-2.0)^{*}$ & S-ALT, $2.82 \mu \mathrm{kat} / \mathrm{L}(0.56)^{*}$ \\
\hline S-DHEAS, 0.9 nmol/L (3.6-12.9)* & S- $\gamma$-GT, $7.49 \mu \mathrm{kat} / \mathrm{L}(0.63)^{*}$ \\
\hline S-FSH, $92 \mathrm{nmol} / \mathrm{L}^{*}$ & \\
\hline $\mathrm{S}-\mathrm{LH}, 31 \mathrm{nmol} / \mathrm{L}^{*}$ & \\
\hline S-cortisol (basal), $238 \mathrm{nmol} / \mathrm{L}(101-536)$ & \\
\hline ACTH stimulated cortisol, $632 \mathrm{nmol} / \mathrm{L}$ & \\
\hline
\end{tabular}

*out of the normal range; $\mathrm{S}$ = serum; DHEAS = dehydroepiandrosterone sulfate; FSH = follicle-stimulating hormone; $\mathrm{LH}=$ luteinizing hormone; $\mathrm{ACTH}=$ adrenocorticotropic hormone; $\mathrm{AST}$ = aspartate aminotransferase; ALT $=$ alanine aminotransferase; $\gamma-\mathrm{GT}=$ gamma-glutamyl transferase

peated (Table 4). We observed normalization of alkaline phosphatase, AST and ALT, and a significant decrease in gamma-glutamyl transferase, which were attributable to the successful GvHD treatment and immunosuppressive treatment cessation.

\section{Discussion}

Premature ovarian insufficiency is very common in women following allogeneic stem cell transplant. Ovaries are more susceptible with higher doses of chemo- therapeutic agents, longer duration of treatment, and use of multiple agents ${ }^{7}$. Artificial premature ovarian failure seemed to be abrupt cessation of reproductive hormonal function which led to impaired QoL. Therefore, HT was extremely important not only to improve her QoL but also to resume her normal life ${ }^{8}$. Usually, for women with POI, a higher dose of estrogen is needed and maintained until the age of natural menopause ${ }^{8,9}$.

Hormone therapy was the gold standard to enable women's life back, so tailoring the dose according to 
Table 3. Green Climacteric Scale after the custom compounded transdermal hormone therapy use

Heart beat quickly and strongly
Feeling tense or nervous
Difficulty in sleeping
Excitable
Attacks of panic
Difficulty in concentrating
Feeling tired or lacking in energy
Loss of interest in most things
Feeling unhappy or depressed
Crying spells

\begin{tabular}{|c|c|c|c|c|c|}
\hline Anxiety & Depression & Sexual & Psychological & Physical & Vasomotor \\
\hline $\begin{array}{l}\text { Average } \\
\text { Woman }\end{array}$ & $>10$ & $>10$ & 7 & 3 & 2 \\
\hline $\begin{array}{l}\text { Average } \\
\text { Menopausal } \\
\text { Woman }\end{array}$ & $>10$ & $>10$ & 12 & 6 & 4 \\
\hline Score 1 & 1 & 1 & 2 & 1 & 2 \\
\hline
\end{tabular}

Table 4. Sex hormones and liver enzymes 3 months after custom compounded transdermal hormone therapy (CC HT) use

\begin{tabular}{|l|l|}
\hline Sex hormones after 3 months of CC HT & Liver enzymes after 3 months of CC HT \\
\hline S-progesterone. $3.08 \mathrm{nmol} / \mathrm{L}(-3.2 \mathrm{nmol} / \mathrm{L})$ & S-alkaline phosphatase. 1.66 \\
S-estradiol, $0.33 \mathrm{nmol} / \mathrm{L}(0-0.11 \mathrm{nmol} / \mathrm{L})$ & S-AST, 0.37 \\
S-SHBG, $31 \mathrm{nmol} / \mathrm{L}(26.1-110.0 \mathrm{nmol} / \mathrm{L})$ & S-ALT, 0.37 \\
S-testosterone $($ free $), 16.1 \mathrm{nmol} / \mathrm{L}(3.5-20.9 \mathrm{nmol} / \mathrm{L})$ & S- $\boldsymbol{\gamma}$-GT, 2.13* \\
S-FSH, $42.7 \mathrm{nmol} / \mathrm{L}$ & \\
S-LH, $23.7 \mathrm{nmol} / \mathrm{L}$ & \\
\hline
\end{tabular}

*out of the normal range; $\mathrm{S}=$ serum; $\mathrm{SHBG}=$ sex hormone binding globulin; $\mathrm{FSH}=$ follicle-stimulating hormone; $\mathrm{LH}=$ luteinizing hormone; AST = aspartate aminotransferase; ALT = alanine aminotransferase; $\gamma$-GT = gamma-glutamyl transferase

the individual purpose was extremely important. The FDA approved HT satisfied most of the purposes for postmenopausal women, unfortunately, there were some exceptions.

The new International Menopause Society (IMS) recommendations for women's midlife health and hormone therapy ${ }^{9}$ do not recommend using so-called 'bio-identical hormones' in the form of CC HT. Nevertheless, in our case, there were some objective obstacles that forced us to prescribe CC HT. Firstly, the woman had impaired liver function. Therefore, oral HT use was contraindicated concerning 'the first pass through the liver'. Secondly, in Slovenia, there was a lack of transdermal FDA HT due to poor interest in HT use. Only one matrix patch system was available (17-beta estradiol, Climara $50 \mathrm{mcg}$ ). There was no gel or cream, either for estrogen or progesterone use. Moreover, transdermal testosterone therapy available in the dose appropriate for the woman was not FDA approved; the testosterone cream was available only in Australia ${ }^{10}$.

Many CC HT prescribers worldwide have mixed estrogens in the form of $\mathrm{Bi}$-Est (estradiol + estrone) or Tri-Est (estradiol + estrone + estriol), which is unnecessary either in terms of hormone metabolism or postmenopausal hormone levels. Estradiol is the main hor- 
mone produced by the ovary that is decreased significantly in postmenopause; estriol is a degraded product of estradiol; and estrone is a hormone that remains almost at the same premenopausal level due to extragenital production from the androgen ${ }^{11-14}$. So, a mixture of all estrogens should not improve QoL in postmenopausal women better than estradiol alone.

Salivary or serum hormone testing is not necessary, especially in order to adjust the dose of the hormone regarding hormone levels in postmenopausal women. There are at least two reasons why hormone testing is not appropriate for adjusting the dose of the hormones: first, estrogen, as well as progesterone or testosterone, have a pulsatile hormone release, so the concentration in serum or saliva changes several times a day; and second, hormone release is connected with dietary patterns and interactions with other medications, so the hormone levels in serum or saliva need not necessarily reflect the hormone levels in the target $\operatorname{organ}^{15,16}$. Hormone testing is reasonable in women with POI to examine the basal pretreatment hormone levels, and repeat testing after 3 months of therapy to follow-up the body response to hormone treatment according to the route of administration. Thus, hormone testing should not be the basis for adjusting the HT dose, but rather an opportunity for patient follow up concerning the prescribed dose and route of administration.

Recent studies confirmed that the risk of venous thromboembolism, as well as its impact on fibrinolytic and coagulation parameters varied according to HT formulation ${ }^{17-21}$. The greatest were recorded in the users of oral estrogen-progestin HT. Transdermal route of administration seems to be much safer, with less side effects concerning thrombotic risk ${ }^{22}$.

Using transdermal micronized progesterone was an issue of great concern regarding endometrial safety. The effectiveness of these preparations in protecting the endometrium is controversial due to the very low serum levels that are achieved. A recent publication has finally confirmed that topical alcohol-based gels appear to yield luteal-phase serum progesterone levels which satisfactorily protect the endometrium ${ }^{23}$. We used liposomal gel, which ensures high bioavailability and deep penetration of progesterone, even better than alcohol-based ge ${ }^{24,25}$. The $10 \%$ progesterone liposomal gel twice daily enables $200 \mathrm{mg}$ micronized progesterone, which ensures safe endometrial protection.
In conclusion, our tasks as practitioners should be the responsibility to achieve the best QoL in our patients with special circumstances, using either FDA approved HT with natural hormones, or CCHT, fulfilling the criteria of individualization and tailoring therapy upon personal needs. Therefore, we could achieve the criteria of good clinical practice in menopausal medicine.

\section{References}

1. Writing Group for the Women's Health Initiative Investigators. Risks and benefits of estrogen plus progestin in healthy postmenopausal women: principal results from the Women's Health Initiative randomized controlled trial. JAMA. 2002; 288:321-33.

2. Ettinger B, Wang SM, Leslie RS, et al. Evolution of postmenopausal hormone therapy between 2002 and 2009. Menopause. 2012;19:610-5. doi: 10.1097/gme.0b013e31823a3e5d.

3. Sprague BL, Trentham-Dietz A, Cronin KA. A sustained decline in postmenopausal hormone use: results from the $\mathrm{Na}$ tional Health and Nutrition Examination Survey, 1999-2010. Obstet Gynecol. 2012;120:595-603. doi: 10.1097/AOG.0b013e318265df42.

4. Burger HG, MacLennan AH, Huang K-E, Castelo-Branco C. Evidence-based assessment of the impact of the WHI on women's health. Climacteric. 2012;15:281-7. doi: 10.3109/13697137.2012.655564

5. Lobo RA. What the future holds for women after menopause: where we have been, where we are, and where we want to go. Climacteric. 2014;17(Supp1 2):12-7. doi: 10.3109/13697137.2014.944497.

6. Ruiz AD, Daniels KR, Barner JC, et al. Effectiveness of compounded bioidentical hormone replacement therapy: an observational cohort study. BMC Women's Health. 2011;11:27. doi: 10.1186/1472-6874-11-27.

7. Panay N, Fenton A. Iatrogenic menopause following gynecological malignancy: time for action! Climacteric. 2016;19(1): 1-2, DOI: $10.3109 / 13697137.2015 .1127640$

8. Franić-Ivanišević $M$, Franić $\mathrm{D}$, Ivović $\mathrm{M}$, Tančić-Gajić $\mathrm{M}, \mathrm{Ma}-$ rina $\mathrm{Lj}$, Barać M, Vujović S. Genetic etiology of primary premature ovarian insufficiency. Acta Clin Croat. 2016;55:629-35. doi: 10.20471/acc.2016.55.04.14

9. Baber RJ, Panay N, Fenton A. The IMS Writing Group 2016 IMS Recommendations on women's midlife health and menopause hormone therapy. Climacteric. 2016;19(2):109-50, DOI: 10.3109/13697137.2015.1129166

10. Spoletini I, Vitale C, Pelliccia F, et al. Androgens and cardiovascular disease in postmenopausal women: a systematic review. Climacteric. 2014;17(6):625-34, DOI: $10.3109 / 13697137.2014 .887669$

11. Speroff L, Fritz MA. Clinical Gynecologic Endocrinology and Infertility, $7^{\text {th }}$ edn. Philadelphia, USA: Lippincott Williams 
\&Wilkins, 2005; p. 634-7. Article in an edited book: Speroff L, Fritz MA. Menopause and the Perimenopausal Transition.

12. Speroff L, Fritz MA. Clinical Gynecologic Endocrinology and Infertility, $7^{\text {th }}$ edn. Philadelphia, USA: Lippincott Williams \&Wilkins, 2005; p. 38-9. Article in an edited book: Speroff L, Fritz MA. Hormone Biosynthesis, Metabolism, and Mechanism of Action.

13. Serin IS, Ozçelik B, Başbuğ M, et al. Long-term effects of continuous oral and transdermal estrogen replacement therapy on sex hormone binding globulin and free testosterone levels. Eur J Obstet Gynecol Reprod Biol. 2001 Dec 1;99(2):222-5.

14. Speroff L, Fritz MA. Clinical Gynecologic Endocrinology and Infertility, $7^{\text {th }}$ edn. Philadelphia, USA: Lippincott Williams \&Wilkins, 2005; p. 700. Article in an edited book: Speroff L, Fritz MA. Postmenopausal Hormone Therapy.

15. Chatterton RT. Validation of hormone testing. In: Proceedings from the Postgraduate Course $17^{\text {th }}$ Annual Meeting of North American Menopause Society, Nashville, 2006; p. 20-2.

16. Fugh-Berman A, Bythrow J. Bioidentical hormones for menopausal hormone therapy: variation on theme. J Gen Intern Med. 2007;22:1030-4.

17. Vogel JJ. Selecting bioidentical hormone therapy. In: Proceedings from the Postgraduate Course $17^{\text {th }}$ Annual Meeting of North American Menopause Society, Nashville, 2006; p. 23-7.

18. Canonico M, Fournier A, Carcaillon L, et al. Postmenopausal hormone therapy and risk of idiopathic venous thromboembolism: results from the E3N cohort study. Arterioscler Thromb Vasc Biol. 2010;30:340-5.
19. Canonico M, Oger E, Plu-Bureau G, et al. Hormone therapy and venous thromboembolism among postmenopausal women: impact of the route of estrogen administration and progestogens: the ESTHER study. Circulation. 2007;115:840-5. doi: 10.1161/ATVBAHA.109.196022

20. Mirkin S, Amadiro JM, Bernick BA, et al. 17b-Estradiol and natural progesterone for menopausal hormone therapy: REPLENISH phase 3 study design of a combination capsule and evidence review. Maturitas. 2015;81:28-35. doi: 10.1016/j. maturitas.2015.02.266.

21. Sweetland S, Beral V, Balkwill A, et al. Venous thromboembolism risk in relation to use of different types of postmenopausal hormone therapy in a large prospective study. J Thromb Haemost. 2012;10(11):2277-86. doi: 10.1111/j.1538-7836.2012.04919.x.

22. Polac I, Borowiecka M, Wiliamowska A, et al. Coagulation and fibrinolytic parameters in women and the effects of hormone therapy; comparison of transdermal and oral administration Gynecol Endocrinol. 2013;29(2):165-8. doi: 10.3109/09513590.2012.730567.

23. Canonico M. Hormone therapy and hemostasis among postmenopausal women: a review. Mneopause. 2014;21(7):753-62. doi: 10.1097/GME.0000000000000296.

24. Stanczyk FZ. Treatment of postmenopausal women with topical progesterone creams and gels: are they effective? Climacteric. 2014;17 (Suppl 2):8-11. doi: 10.3109/13697137.2014.944496.

25. Formulation compendium. www.receptura.com.

Sažetak

\section{INDIVIDUALIZACIJA MAGISTRALNOG HORMONSKOG LIJEČENJA KOD BOLESNICE S KEMOTERAPIJOM INDUCIRANOM PRIJEVREMENOM INSUFICIJENCIJOM JAJNIKA I SMANJENOM JETRENOM FUNKCIJOM: PRIKAZ SLUČAJA}

\section{Franić, M. Sever, A.Janež, M. Franić-Ivanišević i M. Jensterle-Sever}

Premda je upotreba komercijalno pripravljene hormonske terapije u liječenju klimakteričnih simptoma u posljednjih 12 godina u padu, čini se da je upotreba magistralnih hormonskih pripravaka u porastu. Žena u dobi od 39 godina s refraktornom anemijom doživjela je prijevremenu insuficijenciju jajnika nakon transplantacije matičnih stanica. Nakon sistemskog biološkog liječenja azacitidinom i kortikosteroidima, uz izrazite klimakterične tegobe (Greenov indeks 59) i smanjenu kvalitetu života imala je povišene jetrene enzime. Zbog toga nije bila kandidat za oralnu hormonsku terapiju. Započeto je liječenje 17-beta estradiolom u obliku naljepka od $0,5 \mathrm{mg}$ (Climara) zajedno s mikroniziranim progesteronom intravaginalno 2x100 mg (Utrogestan) kroz 3 mjeseca. Nije bila zadovoljna terapijom pa su joj propisani magistralno pripravljeni hormoni. Započelo se s primjenom 17-beta estradiola u obliku $0,5 \mathrm{mg}$ gela $2 \mathrm{x} /$ dan i mikroniziranog progesterona u liposomalnom gelu $100 \mathrm{mg} /$ dnevno. Bolje se je osjećala, ali još uvijek se žalila na smanjeni libido i emocionalnu nestabilnost pa je dodan $1 \%$ testosteron. Sad je bila potpuno zadovoljna terapijom, Greenova klimakterijska ljestvica bila je 8, a jetreni enzimi su se normalizirali. U zaključku, magistralni hormonski pripravci pružaju mogućnost titracije i prilagođavanja terapije individualnim potrebama, što je stalni cilj u menopauzalnoj medicini i mogao bi biti dobra mogućnost za posebne slučajeve.

Ključne riječi: Magistralno pripravljeni hormoni; Individualizacija; Prijevremena insuficijencija jajnika 